\title{
Early post-traumatic splenic arteriovenous fistula in the pancreatic arcade: Diagnosis by volume-rendered $3 \mathrm{D}$ reconstruction images
}

\author{
Junya Tsurukiri, M.D., ${ }^{1}$ Hidefumi Sano, M.D., ${ }^{1}$ Hoshiai Akira, M.D., ${ }^{1}$ Naoyuki Kaneko, M.D. ${ }^{2}$ \\ ${ }^{1}$ Department of Emergency and Critical Care Medicine, Tokyo Medical University Hachioji Medical Center, Tokyo-Japan \\ ${ }^{2}$ Department of Emergency Medicine, Fukaya Red Cross Hospital, Saitama-Japan
}

\begin{abstract}
Arteriovenous fistula (AVF) of splenic vessels is rare. It is most commonly caused by spontaneous rupture of an extant splenic artery aneurysm into an adjacent vein, or by traumatic or iatrogenic pseudoaneurysm. Blunt abdominal trauma can sometimes lead to vascular damage to spleen, resulting in AVF formation. Presently described is case of an elderly patient with high-grade splenic injury. Early post-traumatic AVF was detected by volume-rendered 3D reconstruction using fused arterial and venous phase computed tomography (CT) images.
\end{abstract}

Keywords: Anastomosis; injury; reconstruction; shock; ultrasonography.

\section{INTRODUCTION}

Splenic arteriovenous fistula (AVF) is usually seen as a complication of splenic aneurysm and is not common. Blunt abdominal trauma can sometimes lead to vascular damage to spleen, resulting in AVF formation. Described in the present report is case of an elderly patient with multiple traumas in whom early post-traumatic splenic AVF was detected using computed tomography (CT) angiography.

\section{CASE REPORT}

Written informed consent was obtained from the patient with regard to this report. A 65-year-old woman with history of malignant lymphoma was admitted to emergency center with hemorrhagic shock resulting from a traffic accident. Patient was hemodynamically unstable and immediately received initial trauma resuscitation based on Advanced

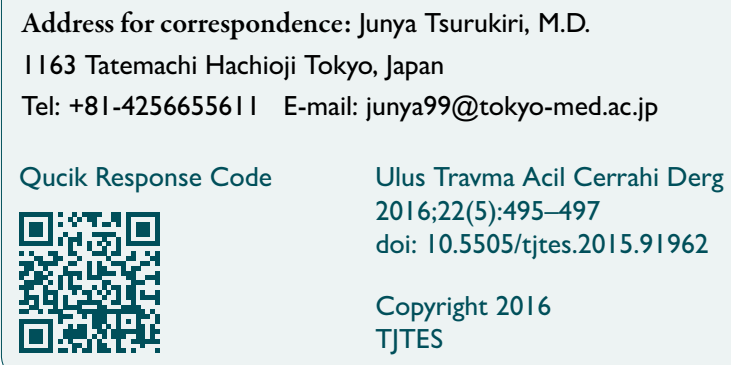

Trauma Life Support (ATLS) guidelines. ${ }^{[l]}$ Focused assessment with sonography for trauma revealed fluid collection around spleen, and X-ray revealed unstable pelvic fractures (Fig. Ia). Values for hemoglobin, hematocrit, platelets, and prothrombin time (PT)-international normalized ratio (INR) were 8.I g/dL (normal range: $11.0-17.0 \mathrm{~g} / \mathrm{dL}$ ), $25.3 \%$ (normal range: $34.0 \%-49.0 \%$ ), $18.9 \times 10^{4} / \mu \mathrm{L}$ (normal range: $14-34 \times 10^{4} / \mu \mathrm{L}$ ) and 1.56, respectively. Initial enhanced CT of abdomen revealed laceration of spleen, classified as CT grade III according to the American Association for the Surgery of Trauma (AAST) CT scale, and fluid collection (Fig. Ib). ${ }^{[2]}$ However, extravasation of contrast medium (CM) was undetectable. Volume-rendered $3 D$ reconstruction using fused arterial and venous phase CT images revealed aneurysm and AVF of an arterial branch arising from lower splenic lobar artery. This branch was evident at ventral side of splenic vein and along edge of the tail of the pancreas on 3D CT (Fig. 2). Pelvic enhanced $C T$ revealed $C M$ extravasations. Successful arterial embolization (AE) of pelvic arteries was performed. Angiography of splenic artery revealed aneurysm and early filling of splenic vein, consistent with AVF detected by 3D CT (Fig. 3a). Although $A E$ of splenic artery was successful, inferior pancreatic artery (IPA) connected to dorsal pancreatic artery (DPA) flowed into aneurysm and AVF (Fig. 3b). After AE of IPA, greater pancreatic artery (GPA) was anastomosed to pancreatic arcade that flowed into the fistula (Fig. 3c). Absence of flow via anastomoses into fistula was confirmed, indicating that $A E$ was successful (Fig. $3 d$ ). Patient was discharged from 

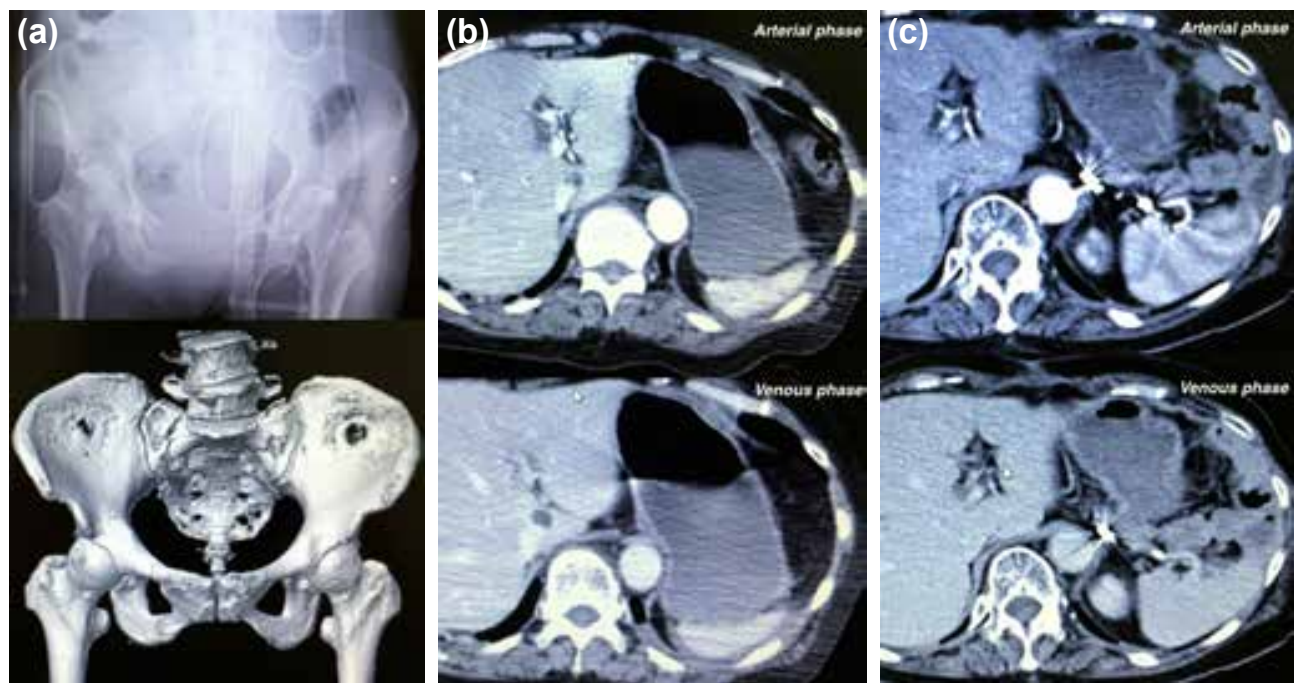

Figure 1. (a) Pelvic X-ray and CT revealed unstable fractures. (b) Initial enhanced CT of abdomen (arterial and venous phase). (c) Enhanced CT of abdomen 3 months after the accident (arterial and venous phase).

intensive care unit (ICU) 60 days after admission and was transferred to another hospital 4 months after the accident. During hospitalization, no signs of acute portal hypertension or mesenteric ischemia such as esophageal varices or ascites were present in CT images or clinical symptoms (Fig. Ic).

\section{DISCUSSION}

AVF of splenic vessels is rare, and it is most commonly caused by spontaneous rupture into an adjacent vein of an extant splenic artery aneurysm, or traumatic or iatrogenic pseudoaneurysm. ${ }^{[3]}$ The former occur more frequently in EhlersDanlos or Osler-Weber-Rendu syndromes. One report describes spontaneous development and rupture of splenic AVF in a patient with lymphoma. ${ }^{[4]}$

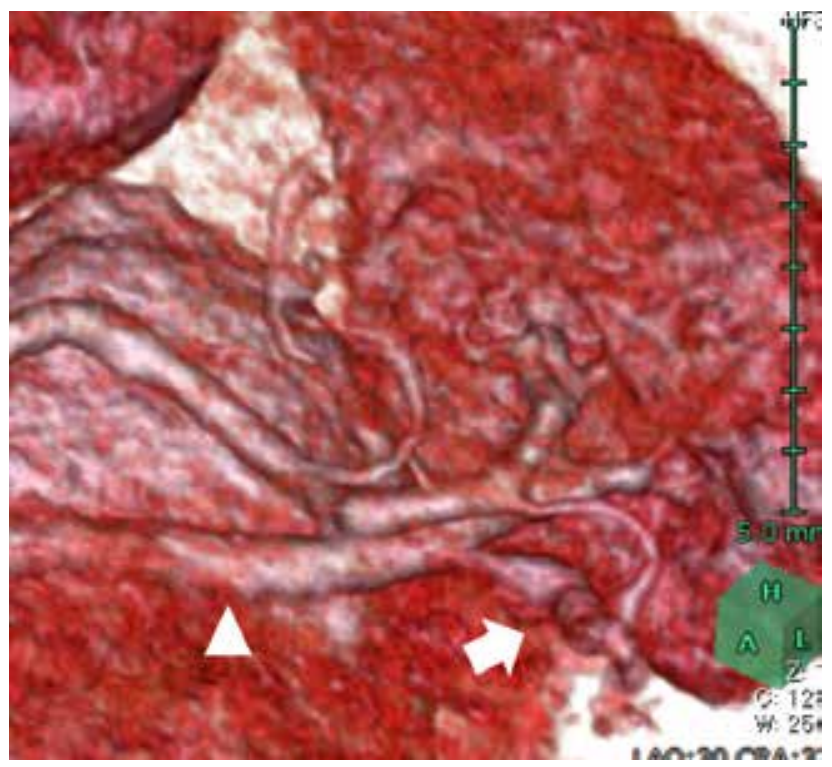

Figure 2. Volume-rendered 3D reconstruction using fused arterial and venous phase CT images showed splenic aneurysm and AVF (arrow) Splenic vein (arrow head).
Nonoperative management (NOM) is a large part of the present strategy for splenic injury. AVF is usually a delayed posttraumatic splenic complication and should be taken into consideration with NOM of splenic injury. An established splenic AVF may be extrasplenic and present as a pulsatile mass, with continuous bruit and thrill, abdominal pain, or diarrhea due to congestion of mesenteric veins. Thus, an early post-traumatic splenic AVF that can cause intra-abdominal hemorrhage, as described in the present report, is considerably rare.

Splenic AVF is diagnosed based on early portal phase findings of arteriography. However, a recent report has suggested that CT angiography is an effective noninvasive method for detection of splenic AVF ${ }^{[5]}$ Although volume-rendered 3D reconstruction of
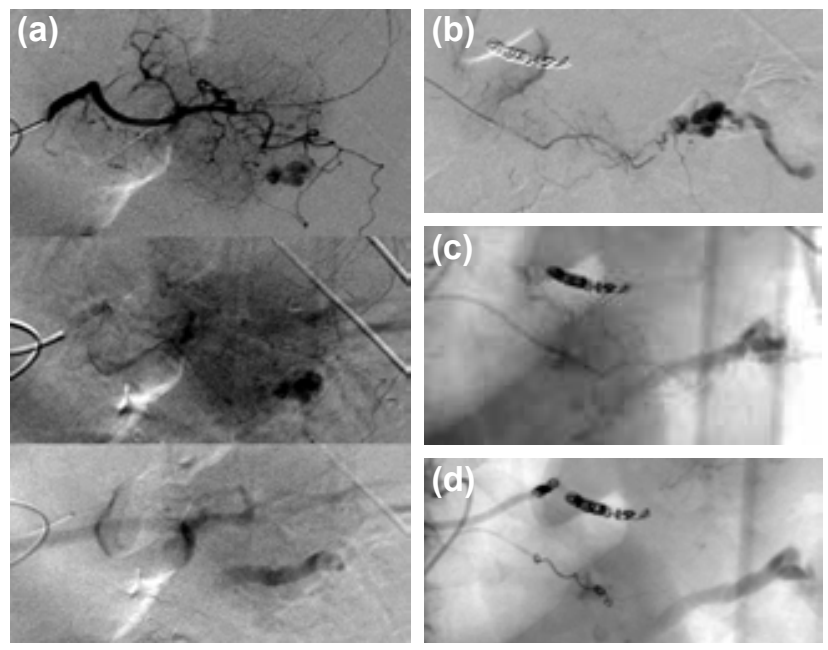

Figure 3. (a) Angiography of splenic artery revealed aneurysm and early filling of splenic vein, consistent with AVF. (b) Inferior pancreatic artery connecting to DPA flowed into aneurysm and AVF. (c) Greater pancreatic artery was anastomosed to pancreatic arcade that flowed into the fistula. (d) The absence of flow via anastomoses into the fistula. 
arterial and venous phase CT scans is useful for such detection, this anatomical site is supplied by a complicated, anastomosing network that originates from splenic artery or DPA. Thus, both 3D CT and angiography are essential to define complex arterial supply to early post-traumatic splenic complications such as AVF so that treatment strategies can be optimized. Treatment of splenic AVF is indicated to avoid portal hypertension, high-output cardiac failure, and other related complications. Therefore, transcatheter arterial embolization is a safe and effective treatment that is an alternative to splenectomy.

\section{Acknowledgments}

The authors would like to thank Enago (www.enago.jp) for the English language review.

Conflict of interest: None declared.

\section{REFERENCES}

1. American College of Surgeons Committee on Trauma. Advanced trauma life support (ATLS) for doctors, 7th ed., Chicago: American College of Surgeons; 2004.

2. Moore EE, Cogbill TH, Jurkovich GJ, Shackford SR, Malangoni MA, Champion HR. Organ injury scaling: spleen and liver (1994 revision). J Trauma 1995;38:323-4. Crossref

3. Maloo MK, Burrows PE, Shamberger RC. Traumatic splenic arteriovenous fistula: splenic conservation by embolization. J Trauma 1999;47:173-5. Crossref

4. van der Meer P, Cossi A, Tsao JI. Splenic arteriovenous fistula in a patient with lymphoma. AJR Am J Roentgenol 1998;171:1377-9. Crossref

5. Oguz B, Cil B, Ekinci S, Karnak I, Akata D, Haliloglu M. Posttraumatic splenic pseudoaneurysm and arteriovenous fistula: diagnosis by computed tomography angiography and treatment by transcatheter embolization. J Pediatr Surg 2005;40:43-6. Crossref

\section{OLGU SUNUMU - ÖZET}

\section{Pankreasta erken evrede oluşan posttravmatik splenik arteriyovenöz fistül: Üç boyutlu volüm rekonstrüksiyon görüntüleriyle tanı \\ Dr. Junya Tsurukiri, ${ }^{1}$ Dr. Hidefumi Sano, ${ }^{1}$ Dr. Hoshiai Akira, ${ }^{1}$ Dr. Naoyuki Kaneko ${ }^{2}$}

${ }^{1}$ Tokyo Tıp Üniversitesi Hachioji Tıp Merkezi, Acil Tıp ve Yoğun Bakım Bölümü, Tokyo-Japonya

${ }^{2}$ Fukaya Kızıl Haç Hastanesi, Acil Tıp Bölümü, Saitama-Japonya

Splenik damarların arteriyovenöz fistülü (AVF) nadirdir. En çok bir komşu vene mevcut bir splenik arter anevrizmasının spontan rüptürü, travma sonucu veya iyatrojenik psödoanevrizma nedeniyle meydana gelmektedir. Künt abdominal travma bazen dalakta vasküler hasara yol açabilmekte sonuçta AVF oluşmaktadır. Burada çok şiddetli splenik travmaya maruz kalmış yaşlı bir hasta tanımlanmıştır. Arteryel ve venöz fazlı bilgisayarlı tomografik (BT) görüntüler kullanılarak gerçekleştirilen üç boyutlu volüm rekonstrüksiyonu posttravmatik AVF erken dönemde tanımlanmıştır.

Anahtar sözcükler: Anastomoz; rekonstrüksiyon; şok; travma; ultrasonografi.

Ulus Travma Acil Cerrahi Derg 2016;22(5):495-497 doi: 10.5505/tjtes.2015.91962 